SCJR 14, no. 1 (2019): 1-2

\title{
Mark D. Nanos Reading Paul within Judaism
}

(Eugene, OR: Cascade, 2017) paperback, xxv + 188 pp.

\author{
MATTHEW V. NOVENSON \\ matthew.novenson@ed.ac.uk \\ University of Edinburgh, New College, Mound Place EH1 2LX, UK
}

It has been nearly a quarter-century since Mark Nanos first made a splash in academic New Testament studies with The Mystery of Romans: The Jewish Context of Paul's Letter (Fortress, 1996). That was before Nanos even finished his St. Andrews Ph.D., the research for which became his second monograph, The Irony of Galatians: Paul's Letter in First-Century Context (Fortress, 2002). In the course of these twenty-plus years, Nanos has also edited some important collections of essays on the Paul and Judaism debates, notably The Galatians Debate (Hendrickson, 2002) and, with Magnus Zetterholm, Paul within Judaism (Fortress, 2015). All the while, he has produced numerous shorter-form journal articles and essays on related topics. It is fitting, then, that Cascade Press is now publishing Nanos's collected essays in several volumes, of which the book under review, Reading Paul within Judaism, is the first. Reading Romans within Judaism (vol. 2) and Reading Corinthians and Philippians within Judaism (vol. 4) have also been published, and Reading Galatians within Judaism (vol. 3) is soon to follow.

The thread running through Nanos's body of work is clearly signalled by the titles of these volumes. His major project is to give an exegesis of all the undisputedly authentic letters of Paul within Judaism. There is an ambiguity, probably deliberate, in the syntax of this phrase. Does is mean that the apostle Paul stood within (late Second Temple) Judaism? Or that Nanos's reading of Paul takes place within (modern, twenty-first century) Judaism? I think the answer is both. Nanos certainly emphasizes the former, historical-critical point. He insists that any talk of Paul teaching or practicing Christianity is irremediably anachronistic. But the essays in this volume also emphasize the latter, hermeneutical point. In chapter 6, aptly titled "Reading Paul in a Jewish Way," he begins by saying, "To speak of reading Paul in a Jewish way can allude to the fact that I am a Jewish person engaged in historical research on Paul... I believe the perspective I bring to the research can be useful to others" (p. 155). 
Nanos's perspective can indeed be useful to others, as is clear from the notes on the places of first publication of the essays here assembled. Most of them began as invited addresses, either to learned societies or to significant ecclesiastical gatherings, on the topic of Paul and Judaism, specifically from Nanos's own perspective as both a Jew and a New Testament scholar. Two of these essays began as addresses at Catholic institutions on the occasion of the Jubilee Year of St. Paul in 2008-2009, one at Villanova University in Philadelphia (chapter 4, "Paul and the Jewish Tradition: The Ideology of the Shema") and one at the Society of St. Paul in Rome (chapter 7, "Paul and Judaism [Codex Pauli]"). Still another (chapter 6, noted above) was an address at the 2015 Deutscher Evangelischer Kirchentag in Stuttgart. Nanos is a historical-critical exegete, but as these examples illustrate, he has also become an important voice in contemporary JewishChristian dialogue.

If the subsequent three volumes of his collected essays comprise exegeses of particular letters, this first volume is programmatic, presenting Nanos's overall research program in a brief two hundred pages. This is clearest of all in the first chapter, by far the longest in the book, "Paul and Judaism: Why Not Paul's Judaism?" (emphasis Nanos's, and a perfect seven-word summary of his overarching thesis). Each of chapters 2 through 6 identifies a point at which exegesis of Paul touches on a problem relevant to Jewish-Christian relations, for instance, chapter 2, "How Inter-Christian Approaches to Paul's Rhetoric Can Perpetuate Negative Valuations of Jewishness-Although Proposing to Avoid That Outcome," and chapter 3, "The Myth of the 'Law-Free' Paul Standing between Christians and Jews."

When Nanos, with a few others, first articulated his Paul-within-Judaism hypothesis in the mid-1990s, it was a decidedly minority view. Nowadays, due in no small part to Nanos's own influence, such an approach is much closer to the mainstream of academic Pauline studies. One consequence of this shift, however, is that there is also much more diversity of interpretation among the numerous scholars who now embrace Nanos's watchword Paul within Judaism. Hence even those readers, like the present reviewer, who are sympathetic with Nanos's methodological premises will nevertheless differ with him on many particular points of interpretation, for instance, his supplying the verb "to seek validation" in his translation of Rom 2:28-29, or his rendering of erga nomou as "rites of a convention" rather than "works of the law," or his claim that Paul's assemblies of gentiles-in-Christ were located socially within diaspora synagogues. But debates over questions like these are the bread and butter of New Testament interpretation, and whatever disagreements there may be, I suspect that Mark Nanos is gratified to know that we are all now having the conversation that he helped start back in the 1990s. 